\title{
PRODUCTIVE PERFORMANCE AND HISTOLOGICAL RESPONSES OF JAPANESE QUAIL BREEDERS TO AGE AT MATING AND SILVER NANOPARTICLES ADMINISTRATION
}

\author{
Nafisa A. Abd El-Azeem ${ }^{1}$, M. Madkour ${ }^{1}$, O. M. Aboelazab ${ }^{1}$ and I. El-Wardany ${ }^{2}$ \\ ${ }^{1}$ Department of Animal Production, National Research Centre, Dokki, Giza, Egypt. \\ ${ }^{2}$ Department of Poultry Production, Faculty of Agriculture, Ain Shams Univ., Shoubra El-Kheima, \\ Cairo, Egypt
}

(Received 4/9/2018, accepted 22/10/2018)

\section{SUMMARY}

\begin{abstract}
A total of 64 males and 192 females of Japanese quail breeders (Coturnix coturnix japonica) were divided into two groups of different ages (old birds; 52 weeks of age and young birds; 10 weeks of age). These subgroups were used in a series of four natural mating groups in a regular and reciprocal manner. In the $1^{\text {st }}$ and $2^{\text {nd }}$ mating groups; old males were paired with young and old females, respectively. While the $3^{\text {rd }}$ and the $4^{\text {th }}$ groups; young males were paired with young and old females, respectively. The first and the second subgroups of both ages (young and old) were subjected to a treatment of 20 ppm silver nanoparticles (AgNps) in drinking water. The third and fourth ones were used as a control treatment given fresh water with no supplement. Egg production parameters, feed consumption and feed conversion ratio were recorded biweekly. At the last week of the experimental period ( $\left.8^{\text {th }} \mathrm{wk}\right)$, birds were weighed and slaughtered, autopsied and some organs were weighed. Histological observation was done for liver, ileum, testis and sperm storage tubules of hens. The results showed that older age of quail had significantly higher egg weights compared to those produced from the younger ones. Also, administration of AgNps improved live body weight (LBW) and egg weight of female Japanese quail breeder hens. Insignificant interaction between both age at mating and silver nanoparticles was found on feed consumption (FC), feed conversion ratio (FCR) and body weight (BW). Histological examinations showed that AgNps may have minor negative impacts on the liver and ileum tissues of laying quails. It could be concluded from the present study that; it is possible to improve the productive performance and healthy status of aged Japanese quail breeder stocks if the old age female breeders are mated with younger male ones. The magnitude of this effect could be achieved through the administration of $\mathrm{AgNps}$ in their drinking water.
\end{abstract}

Keywords: age at mating, egg production, silver nanoparticles, histological response, Japanese quail breeder.

\section{INTRODUCTION}

Quails have an economical importance as they provide an alternative to the commonly used chickens. Quail production in Egypt is rapidly growing, primarily because these birds do not require much space, easy to manage and reproductively mature in six weeks. Presently, Japanese quail (Coturnix coturnix japonica) are produced mainly for their meat and eggs, that have become highly popular to the consumers.

For improving the reproduction of breeder flocks, manipulating the physiological and environmental factors is necessary. Among the physiological factors that necessary for production and reproduction are age, body weight, hormones and sex ratio. The quail breeder age and age at mating are important factors affecting egg weight and egg production (El-Wardany et al., 2016). The egg production can be affected by several factors such as feed consumption (quality and quantity), drinking water, intensity and duration of light, management, environment, stresses, immunosuppression, parasite infestation, exposure to disease and toxins, which all can result in economic loss. Nanotechnology is the promising and emerging technology that has tremendous potential to revolutionize agriculture and livestock sectors globally (Gopi et al., 2017). Silver nanoparticles (AgNPs) are of interest due to their antimicrobial activity and are seen as potential candidates to replace antibiotics in animal husbandry (Sawosz et al., 2012). 
Supplementation of silver nanoparticles (AgNPs) improved the stomach internal environment for aged birds (Xia et al., 2017). Approximately 80\% of the silver in AgNPs was in the metallic form and the remaining silver was in ionic form. Ionic silver become silver chloride in the stomach or blood stream. However, only metallic particles can resist high acidity stomach of birds and remain effective in the blood stream. Silver has been known for its medicinal properties, especially as an antimicrobial agent, but it may be toxic when it is in ionic state. However, the toxicity of $\mathrm{Ag}$ can be eliminated, when used in nanoparticle form. Moreover, AgNPs affects performance, intestinal microflora and morphology of enterocytes of duodenal villi of quail, (Farzinpour and Karashi, 2013; El-Wardany et al., 2016 and Rezaei et al., 2018).

Therefore, the purpose of the present study was to elucidate the interactions between AgNPs in drinking water and age of quail breeder males and females at mating on: body weight, feed intake, feed conversion and egg production of Japanese quail breeder hens and the histological changes of uterovaginal junction of breeder females, as well as their liver and ileum.

\section{MATERIALS AND METHODS}

\section{Experimental design and management:}

A total of 64 males and 192 females of Japanese quail breeders flock (Coturnix coturnix japonica) represent two equal groups of different ages (old birds; 52 weeks of age and young birds; 10 weeks of age) were used in this study. Breeders of each age were randomly subdivided into 4 subgroups resulting in 8 subgroups each of 8 males and 24 females. Birds were kept in an individual wire cage system $(18 \times 18 \mathrm{~cm})$ with a sloping floor for egg collection. These 8 subgroups were used in a series of four natural mating groups, each of 2 replicates, in a regular and reciprocal manner. In the $1^{\text {st }}$ and $2^{\text {nd }}$ mating groups, old males were paired with young and old females, respectively. While for the $3^{\text {rd }}$ and the $4^{\text {th }}$ groups, young males were paired with young and old females, respectively. For all mating groups, the sex ratio was $1 \hat{\jmath}: 3$ q, thus each male was caged with each female for a period of $24 \mathrm{~h}$.

Birds of one replicate within each of the four mating groups were offered drinking water supplemented with 20 ppm silver nanoparticles (AgNPs). Silver nanoparticles were obtained from International Care American Company. Silver nanoparticles concentration used in this study was based on the literature review. The experiment was extended for 8 weeks. While the other replicate within each mating was used as control treatments given fresh water with no AgNPs supplement. All birds were kept in a windowed house, fed adlibitum on a diet which was formulated to meet the nutrients requirement of Japanese quail breeders according to NRC (1994). Drinking water was available all the time. Birds were exposed to a light cycle of $16 \mathrm{~h}$ light and $8 \mathrm{~h}$ dark throughout the experimental period.

\section{Productive performance:}

Live body weights (LBW) of female and male breeders were recorded at biweekly intervals. Individual egg weight and egg number were recorded daily through 8 wks of experimental period. Average egg weight and egg number were calculated for each replicate and treatment. Egg mass was calculated as egg production multiplied by average egg weight. Feed consumption was recorded weekly for each replicate and the average feed consumption/bird/day was calculated. Feed conversion ratio (FCR) was calculated as gram feed consumed per gram egg produced ( $\mathrm{g}$ feed/g egg mass).

\section{Slaughter traits:}

At the end of the experimental period, three females and three males from each treatment were randomly selected and weighed using digital electronic balance, (Precisa digital electronic balance, PJ 57604, Switzerland). Their weights were recorded to the nearest 0.1 gram. Birds were slaughtered by severing the carotid arteries and jugular veins, after complete exsanguination they were autopsied. At autopsy, the abdominal cavity was opened. sex organs; (ovary, oviduct and testes) were removed and weighed. Their weights were recorded to the nearest $0.1 \mathrm{mg}$, and proportionated to the live body weights.

\section{Histological study:}

Tissue samples from liver, ileum and reproductive organs i.e. uterovaginal junction and testis were taken during the slaughtering time. Tissues were fixed in $10 \%$ formalin saline solution. Tissues were dehydrated in ascending grades of ethanol, and then cleared in xylene. Then embedded in paraffin wax. The paraffin 
technique has been done according to Abd El-Hamid (1981). Transverse sections (4-5 $\mu \mathrm{m}$ thick) were done using a rotary microtome. All sections were stained with hematoxylin and eosin (H\&E) stains. Sections were examined under light microscope and photographed by using computerized digital camera (iVU 3000) endorsed with software (ProgRes® CapturePro 2.707, 2010). The histological technique of tissues samples was conducted in the Pathology Laboratory, Faculty of Veterinary Medicine, Cairo University, Egypt.

\section{Statistical analysis:}

Data of the present study were subjected to a two-way analysis of variance with age at mating and drinking water sliver nanoparticles treatment $(\mathrm{N})$ as the main effects using the General Linear Models (GLM) procedure of SAS (1998). The following model was used:

$$
\mathrm{Y}_{\mathrm{ijk}}=\mu+\mathrm{M}_{\mathrm{i}}+\mathrm{N}_{\mathrm{j}}+\mathrm{MN}_{\mathrm{ij}}+\mathfrak{f}_{\mathrm{ijk}}
$$

Where: $Y_{i j k}=$ the observation, $\mu=$ an effect of overall mean, $M_{i}=$ a fixed effect of $i$ (age at mating), $N_{j}=$ a fixed effect of $j$ (silver nano-particle treatment), $M N_{i j}=$ the interaction of $i$ age at mating and the $j$ silver nano-particle treatment, and $£_{\mathrm{ijk}}=$ a random experimental error.

Duncan's multiple range test (Duncan, 1955) was used to separate difference among treatment means when separation was relevant. All Percentage data were subjected to arcsine transformation of the square root before statistically reanalyzed however, the actual percentage means are presented. Difference was considered significant at $(\mathrm{P}<0.05)$.

\section{RESULTS AND DISCUSSION}

\section{Egg production traits:}

The parental age at mating had a significant effect on egg weight as shown in Table (1). It is clear that after two weeks of treatments, the Japanese quail female (treatment 2,4 ) had significantly higher egg weight $(\mathrm{P}<0.01)$ compared to those produced from the younger ones regardless of males age. A similar trend was also observed for the whole laying period $(0-8 \mathrm{wk})$. However, the age at mating had a remarkable significant improvement in the egg weight, but not the administration of AgNps. The increased egg weight is due mainly to age of females and to the changes in ovarian hormones secretion rates with age. This may be due to effect of estrogens which increases at the peak of egg production (Hansen et al., 2003). Also, the synthesis and secretion of egg albumen by the oviduct is under estrogenic control (Christians and Williams, 1999).

These results are similar to the findings of Silversides and Scott (2001) and Erensayin et al. (2002). They reported a linear relationship between the egg weight and the age of female quail. Moreover, Ipek et al. (2004) revealed that egg weight was increased significantly with increasing Japanese breeder age. In this connection, Bahie El-Deen et al. (2008 and 2009) found that the mean egg weight of quail was $10.96 \mathrm{~g}$ during the first 45 days after sexual maturity, and reached to $11.07 \mathrm{~g}$ during 90 days of laying. The differences in egg weight refer to variation in body weight and age of quails. It has been reported that the mean egg weight in Japanese quails was $10 \mathrm{~g}$, and generally exhibited an increase up to five months of breeder age (Nazligül et al., 2001). It is well known that, eggs production depends on many factors including the length of the laying cycle, some physiological and nutritional effects and also is related to body weight of the bird at sexual maturity (Meky 2007; Bahie El-Deen et al., 2008 and 2009). The present results showed that live body weight of laying quails was significantly heavier $(\mathrm{P}<0.05)$ in AgNps treatment groups than the non-administered groups. This coincident with the higher egg weight, especially for M2 (old $\delta$ x old $\rho$ ) group. This could be explained by the highly significant effect of the interaction between age at mating and $\mathrm{AgNps}$ treatment. It may be that the effect of AgNps was more obvious in older groups than younger ones, probably by improving their physiological status. This was also reported by Sawosz et al. (2007).

It appears that AgNps could improve egg weight via its effect as antimicrobial drug and or by enhancing feed utilization by reducing intestine $\mathrm{pH}$ which in turn influences the development of lactic acid bacteria and E. coli colonies. In this respect, Sawosz et al. (2009) reported that $25 \mathrm{ppm}$ of AgNps did not adversely affect intestinal villi morphology of quails but increased significantly the populations of lactic acid bacteria. Our results are in close agreement with those reported by Fondevila et al. (2009) who found a significant increase in egg weight of laying quails after AgNps administration at a level of $20 \mathrm{ppm}$. 
Table (1): Effect of age at mating and silver nanoparticles administration on egg production traits of Japanese quail breeder hens.

\begin{tabular}{|c|c|c|c|c|c|c|c|c|c|}
\hline \multirow{2}{*}{$\begin{array}{l}\text { Period } \\
\text { (wk) }\end{array}$} & \multirow{2}{*}{$\begin{array}{l}\text { Nanosilver } \\
(\mathrm{N})\end{array}$} & \multicolumn{4}{|c|}{ Mating system (M) } & \multirow[b]{2}{*}{$\begin{array}{c}\text { Overall } \\
\text { mean }\end{array}$} & \multicolumn{3}{|c|}{ Significance } \\
\hline & & 1 & 2 & 3 & 4 & & $\mathrm{M}$ & $\mathrm{N}$ & $\mathrm{M} * \mathrm{~N}$ \\
\hline \multicolumn{10}{|c|}{ Average egg weight $(\mathrm{g})$} \\
\hline \multirow{3}{*}{$(0-8)$} & $\mathrm{N}_{0}$ & $11.4 \pm 0.12$ & $12.4 \pm 0.10$ & $11.8 \pm 0.24$ & $11.6 \pm 0.05$ & 11.80 & & & \\
\hline & $\mathrm{N}_{1}$ & $11.8 \pm 0.05$ & $12.3 \pm 0.03$ & $11.7 \pm 0.09$ & $12.6 \pm 0.32$ & 12.10 & & & \\
\hline & $\begin{array}{c}\text { Overall } \\
\text { mean }\end{array}$ & $11.60^{\mathrm{c}}$ & $12.35^{\mathrm{a}}$ & $11.75^{\mathrm{bc}}$ & $12.10^{\mathrm{ab}}$ & & $* *$ & NS & $*$ \\
\hline \multicolumn{10}{|c|}{ Egg number (number/ hen/wk) } \\
\hline \multirow{3}{*}{$(0-8)$} & $\mathrm{N}_{0}$ & $5.77 \pm 0.12$ & $4.65 \pm 0.14$ & $5.63 \pm 0.31$ & $4.97 \pm 0.24$ & 5.26 & & & \\
\hline & $\mathrm{N}_{1}$ & $4.56 \pm 0.16$ & $5.61 \pm 0.04$ & $5.46 \pm 0.15$ & $4.44 \pm 0.12$ & 5.02 & & & \\
\hline & $\begin{array}{c}\text { Overall } \\
\text { mean }\end{array}$ & $5.17^{\mathrm{ab}}$ & $5.13^{\mathrm{b}}$ & $5.55^{\mathrm{a}}$ & $4.70^{\mathrm{c}}$ & & $* *$ & NS & $* *$ \\
\hline \multicolumn{10}{|c|}{ Egg mass (g/hen/wk) } \\
\hline \multirow{3}{*}{$(0-8)$} & $\mathrm{N}_{0}$ & $66.0 \pm 0.62$ & $57.4 \pm 1.23$ & $66.7 \pm 4.98$ & $57.8 \pm 3.02$ & 61.98 & & & \\
\hline & $\mathrm{N}_{1}$ & $53.6 \pm 2.05$ & $68.7 \pm 0.89$ & $63.7 \pm 2.17$ & $55.8 \pm 0.09$ & 60.45 & & & \\
\hline & $\begin{array}{c}\text { Overall } \\
\text { mean }\end{array}$ & $59.80^{\mathrm{ab}}$ & $63.05^{\mathrm{a}}$ & $65.20^{\mathrm{a}}$ & $56.80^{\mathrm{b}}$ & & $*$ & NS & $*$ \\
\hline \multicolumn{10}{|c|}{ Feed consumption (g/hen/wk) } \\
\hline \multirow{3}{*}{$(0-8)$} & $\mathrm{N}_{0}$ & $178.9 \pm 1.6$ & $185.0 \pm 1.1$ & $181.3 \pm 3.9$ & $179.1 \pm 1.4$ & 181.1 & & & \\
\hline & $\mathrm{N}_{1}$ & $177.0 \pm 1.2$ & $186.4 \pm 1.2$ & $177.9 \pm 1.8$ & $183.1 \pm 2.1$ & 181.1 & & & \\
\hline & $\begin{array}{c}\text { Overall } \\
\text { mean }\end{array}$ & 177.9 & 185.7 & 179.6 & 181.1 & & NS & NS & NS \\
\hline \multicolumn{10}{|c|}{ Feed conversion ratio ( $\mathrm{g}$ feed: $\mathrm{g}$ egg mass) } \\
\hline \multirow{3}{*}{$(0-8)$} & $\mathrm{N}_{0}$ & $2.71 \pm 0.05$ & $3.22 \pm 0.09$ & $2.72 \pm 0.15$ & $3.10 \pm 0.02$ & 2.94 & & & \\
\hline & $\mathrm{N}_{1}$ & $3.30 \pm 0.05$ & $2.71 \pm 0.16$ & $2.79 \pm 0.07$ & $3.28 \pm 1.03$ & 3.02 & & & \\
\hline & $\begin{array}{c}\text { Overall } \\
\text { mean }\end{array}$ & $3.01^{\mathrm{b}}$ & $2.97^{\mathrm{b}}$ & $2.76^{\mathrm{c}}$ & $3.19^{\mathrm{a}}$ & & $* *$ & NS & NS \\
\hline
\end{tabular}

As shown in Table (1), the results indicate that, the highest values for egg number have been recorded for younger hens whether mated with young or old males, compared to older ones. Additionally, no significant effects due to AgNps administration on egg number were observed. The achieved improvement in egg production for the young hens is associated with higher circulating estrogen hormone level comparable to the old ones. Khalifa et al. (1983) referred the increase in egg production number to the physiological effect of estrogen upon the ovary and oviduct causing enhancing their ovulatory process, consequently increased

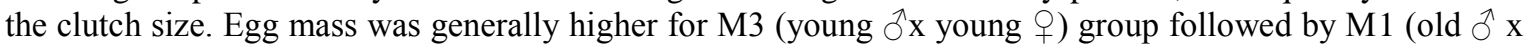
young $_{\text {) }}$ mating groups, respectively. While, the lower values were recorded for M4 (young $\delta$ x old $q$ ) and M2 (old $\hat{\partial} \mathrm{x}$ old 9 ) groups (Table 1). Increasing egg mass may reflect an improvement in egg weight and /or egg number, which was achieved for M3 and M1 mating groups. These results are in close agreement with Bahie El-Deen et al. (2008 and 2009) who reported similar values for egg mass during the first 45 days after sexual maturity, and lower values during a period of 90 days, as birds become older.

The results indicated that, over the whole period of the study (0-8wk) there were no significant differences between all groups of mating treatments, as well as the administration of AgNps and the interaction with respect to feed consumption (Table 1). The present finding is coincided with those reported by Ahmadi (2012), who found that dietary supplementation of AgNps between 20 and 60 ppm had no significant effect on feed consumption of broiler chicks compared with un-supplemented chicks. Feed 
conversion ratio, as one of the most important factors of economic productivity, was significantly improved $(\mathrm{P}<0.01)$ at $2 \mathrm{wks}, 4 \mathrm{wks}$ and for the whole period $(0-8 \mathrm{wks})$ with the younger age group, especially for M3 (young $\hat{\partial} \mathrm{x}$ young q) compared to the other treatments. However, the interaction between both age at mating and $\mathrm{AgNps}$ administration was not significant for feed conversion ratio (Table1).

\section{Live body weight (LBW) and reproductive organs:}

Table (2), illustrates the effect of AgNps administration in drinking water and different age at mating on LBW of female Japanese quail breeders' hens. There was non-significant increase associated with age in LBW from the beginning till the end of treatment. This trend is in fact due to the differences in the initial LBW of different mating groups with the young females having lower body weight (M1 and M3) than (M2 and M4). The effect of AgNps on LBW of females was significant $(\mathrm{P}<0.01)$ at 8 wks post-treatment which may reflect a positive response of laying quails to AgNps administration. This could be account for the beneficial effect of AgNps administration on intestinal microbial population, as an antipathogenic material. Thus, AgNps affect bacterial membrane leading to structural changes and consequently death of the pathogenic microorganisms (Sondi and Salopek-Sondi, 2004 and Maranbio- Jones and Hoek, 2010).

Table (2): Effect of age at mating and silver nanoparticles administration on average body weight and reproductive organs relative weights of Japanese quail breeder hens.

\begin{tabular}{|c|c|c|c|c|c|c|c|c|c|}
\hline \multirow{2}{*}{$\begin{array}{l}\text { Nanosilver } \\
\text { (N) }\end{array}$} & \multicolumn{4}{|c|}{ Mating system (M) } & \multirow{2}{*}{$\begin{array}{c}\text { Overall } \\
\text { mean }\end{array}$} & \multicolumn{4}{|c|}{ Significance } \\
\hline & 1 & 2 & 3 & 4 & & $\mathrm{M}$ & $\mathrm{NI}$ & $M^{*} \mathrm{I}$ & \\
\hline \multicolumn{10}{|c|}{ Average body weight (g/hen) } \\
\hline $\mathrm{N}_{0}$ & $238 \pm 4.2$ & $249 \pm 3.7$ & $242 \pm 4.4$ & $240 \pm 6.4$ & $242^{\mathrm{b}}$ & & & & \\
\hline $\mathrm{N}_{1}$ & $244 \pm 5.7$ & $255 \pm 5.2$ & $247 \pm 2.8$ & $262 \pm 6.3$ & $252^{\mathrm{a}}$ & & & & \\
\hline Overall mean & 241 & 252 & 245 & 251 & & NS & $* * 1$ & NS & \\
\hline \multicolumn{10}{|c|}{ Ovary $(\%)$} \\
\hline $\mathrm{N}_{0}$ & $1.34 \pm 0.08$ & $1.61 \pm 0.16$ & $2.56 \pm 0.09$ & $1.53 \pm 0.07$ & $1.76^{\mathrm{b}}$ & & & & \\
\hline $\mathrm{N}_{1}$ & $2.57 \pm 0.31$ & $1.75 \pm 0.04$ & $3.04 \pm 0.29$ & $1.61 \pm 0.37$ & $2.24^{\mathrm{a}}$ & & & & \\
\hline Overall mean & $1.96^{\mathrm{b}}$ & $1.68^{\mathrm{b}}$ & $2.80^{\mathrm{a}}$ & $1.57^{\mathrm{b}}$ & & $* *$ & $* *$ & * & $*$ \\
\hline \multicolumn{10}{|c|}{ Oviduct (\%) } \\
\hline $\mathrm{N}_{0}$ & $3.18 \pm 0.03$ & $3.13 \pm 0.16$ & $3.69 \pm 0.19$ & $2.81 \pm 0.28$ & 3.20 & & & & \\
\hline $\mathrm{N}_{1}$ & $3.31 \pm 0.16$ & $2.79 \pm 0.22$ & $4.22 \pm 0.35$ & $2.64 \pm 0.08$ & 3.24 & & & & \\
\hline Overall mean & $3.25^{\mathrm{b}}$ & $2.96^{\mathrm{bc}}$ & $3.96^{\mathrm{a}}$ & $2.73^{\mathrm{c}}$ & & $* *$ & NS & $S \mathrm{~N}$ & JS \\
\hline \multicolumn{10}{|c|}{ Testis (\%) } \\
\hline $\mathrm{N}_{0}$ & $2.63 \pm 0.38$ & $3.64 \pm 0.30$ & $2.52 \pm 0.32$ & $2.62 \pm 0.13$ & 2.85 & & & & \\
\hline $\mathrm{N}_{1}$ & $2.77 \pm 0.18$ & $2.06 \pm 0.58$ & $2.71 \pm 0.15$ & $2.45 \pm 0.14$ & 2.50 & & & & \\
\hline Overall mean & 2.70 & 2.85 & 2.62 & 2.54 & & NS & NS & $S \quad N$ & JS \\
\hline
\end{tabular}

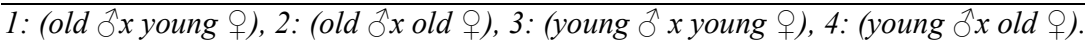

N0: (Zero nanosilver), N1: (20ppm nanosliver). $* P \leq 0.05 \quad * * P \leq 0.01 \quad$ NS: non-significant.

Mean within a column (having capital letters) or row (having small letters) are significantly different.

In general, the results of productive performance in the present study are in close agreement with the findings by Ayorinde and Oke (1995) who reported that the variation in body weight within a flock might be due to genetic variation and environmental factors which in turn affect the profitability of egg production. However, there was a tendency for egg number, egg weight, yolk weight and albumen weight to increase as body weight and age increased. Agaviezor et al. (2008) stated that body weight has been shown to 


\section{Abd El-Azeem et al.}

significantly determine the performance and the economic value of the hen. Furthermore, the present results indicated that age at mating, AgNps and their interaction were significantly $(\mathrm{P}<0.01)$ increased ovary relative weight, especially in young female group (M3) followed by M1 group. A similar trend was also observed for the relative weight of the oviduct in respect of age at mating, however, no significant influence of AgNps nor the interaction were observed. The testis relative weight was not significantly changed with either age at mating or AgNps administration and also their interaction. However, there was numerical increase in testis percentage of old males (M1, M2) compared with young males (M3, M4). From the present results, it appears that the increase in ovary and oviduct relative weights in young females may be due to age-related changes in the ovarian function of laying quails.

It is well known that there are four to six large yolk-filled follicles accompanied a great number of small yellow follicles in which yellow yolk deposition has been initiated, and numerous small white follicles (Johnson, 2000). Regardless, the large follicles, it is clear that the number and weight of the other small follicles and the ovarian stroma weight may determine the ovary weight. In this concern, the number of atretic follicles and the rate of follicular atresia may influence the ovary weight in aged quail. This atresia occurs with high incidence in the prehierarcheal follicles as a natural physiological phenomenon which is regulated by many factors including, age, nutrition and environment (Gilbert et al., 1983 and Yoshimura et al., 1994). These findings confirm our results with respect to the ovary weight. Moreover, the increase in oviduct percentage of young females might be attributed to the increase in plasma levels of sex steroid hormones that are responsible for the development of the oviduct in terms of hyperplasia of the epithelium lining of all segments, submucosal development of tubular glands coincident with the increase in the synthesis and accumulation of the specific water-soluble protein. This is in close agreement with the findings of many workers who stated that estrogen (either endogenous or exogenous) promotes the formation of tubular secretary glands and induces the synthesis of ovalbumin, conalbumin, ovomucoid and avidin (Pageaux et al., 1984; Lien et al., 1985; Abdel-Fattah, 1999; El-Afifi and Abo-Taleb, 2002; Holmes et al., 2003., Ottinger et al., 2004). The lack of the significant influence of males age on testes relative weight in the present study could be explained by the fact that male quails undergo gradual reproductive decline, in contrast, to females. This may be related to the loss in plasma testosterone levels, which is coincided with the reduced baseline GnRH-I release from hypothalamic centers. This was also reported and reviewed by Ottinger et al. (2004).

\section{Histological observations:}

\section{Liver histology:}

Histological examination of liver sections for Japanese quail breeder hens as influenced by age and AgNps administration are shown in Figures 1-a to 1-h. It is clear from Fig.1-a and 1-b (old hens) that the hepatocytes of these sections showed normal appearance and structure, however some unfilterable fluids and fatty cirrhotic areas could be seen. The portal vein is greatly dilated which may reflect hyperactive response of liver tissues to the progressive demands for egg yolk formation. This was also observed liver sections of old hens in Fig. 1-c and 1-d. However, many congested liver areas are detected with some necrotic areas and an extended portal vein filled with numerous erythrocytes. Many dark stained areas with hypertrophic liver cells are also present, especially in Fig. 1-d.

In Fig. 1-e and 1-f, where young females were mated with old males, the microscopic examination of liver section showed normal histological structure without any degenerative changes in the hepatocytes and the portal vein, except few unfilterable fluid areas is observed. This may indicate the impact of hen age on the physiological status of all vital organs in the body. This concept was not observed in the liver tissues of hens with similar age, but $20 \mathrm{ppm}$ AgNps was added to their drinking water (Fig. 1-g). In this section many congested sinusoids could be seen along with pale-stained areas indicative of some side effects of AgNps on liver tissues. A similar observation could be seen in Fig. 1-h where AgNps administration caused many necrotic areas with mild infiltration of inflammatory cells in the liver parenchyma. The above-mentioned changes in the liver sections are due mainly to AgNps administration with a minor effect of males age. The deleterious structural changes which had been detected in old hens is due to hen age along with AgNps administration. It is likely that AgNps as antimicrobial and antifungal drug may have negative impact on the liver tissue of laying quails. This effect was more obvious in old females than young ones. These results disagree the findings by Ahmadi et al. (2009) who reported that different levels of AgNps (0 to $900 \mathrm{ppm})$ had no significant effect on liver histology of broiler chickens. However, Loghman et al. (2012) and Rezaei et al. (2018) have found that administration of 0-12 ppm AgNps causes a dose-dependent changes in liver 
cells of broiler chicks and laying quails, respectively. In the present study, only one dose was applied (20 ppm) for laying quails which may explain the differences in this respect.

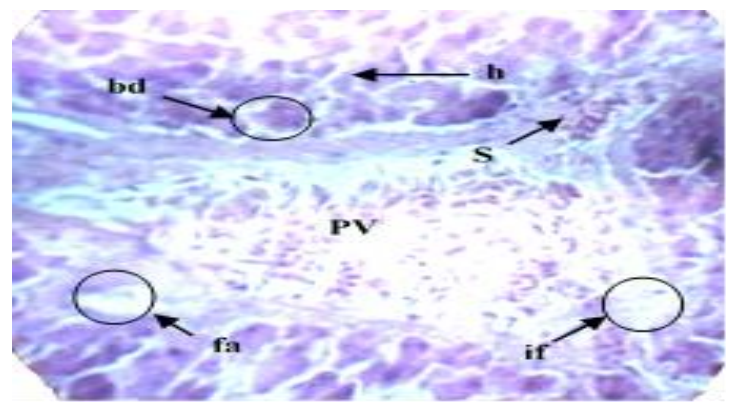

Fig. (1-a) T.S. in the liver of hens from the mating group 2, without AgNps administration (H\&E x 200).

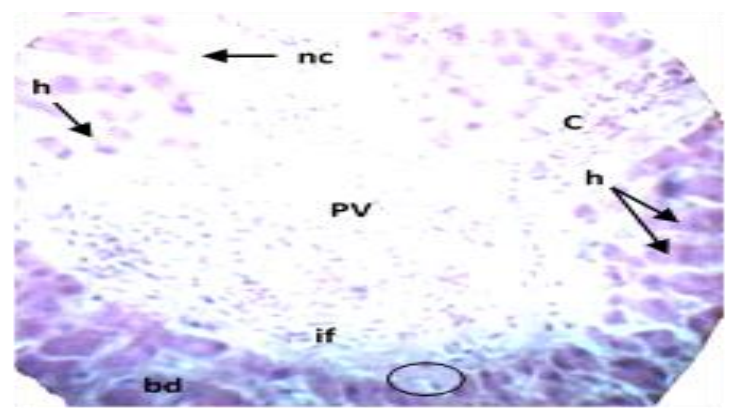

Fig. (1-c) T. S. in the liver of hens from the mating group 2, with AgNps administration

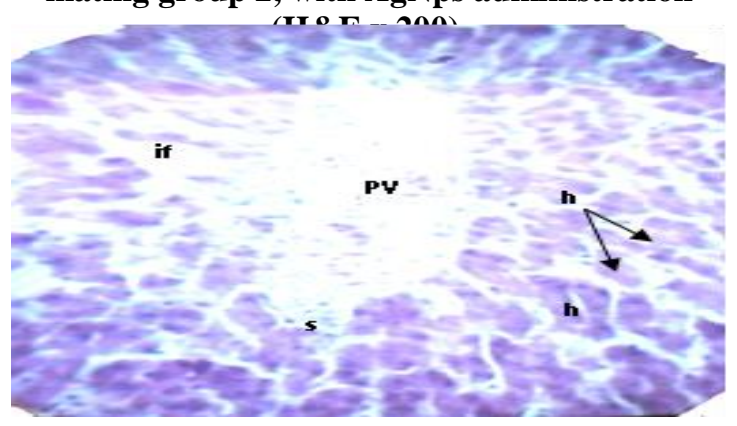

Fig. (1-e) T.S. in the liver of hens from the mating group 1, without AgNps administration (H\&E x 200).

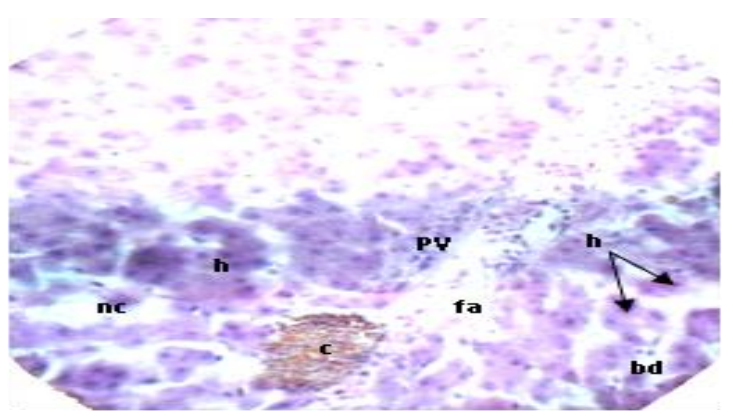

Fig. (1-g) T. S. in the liver of hens from the mating group 1, with AgNps administration

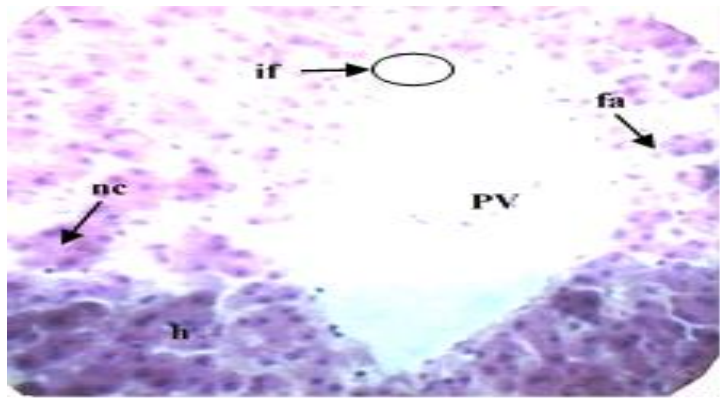

Fig. (1-b) T.S. in the liver of hens from the mating group 4, without AgNps administration (H\&E x 200).

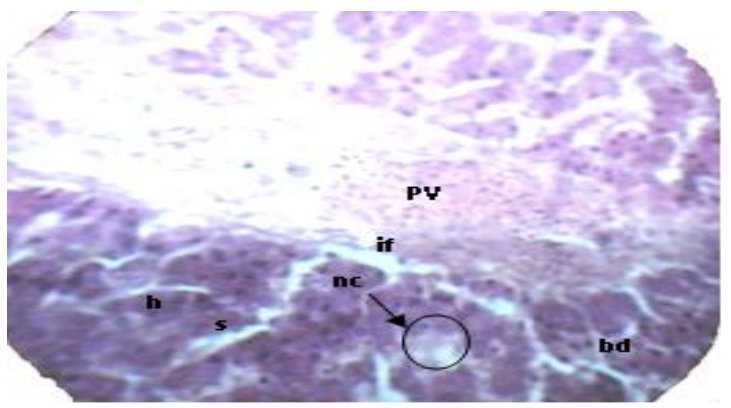

Fig. (1-d) T.S. in the liver of hens from the mating group 4, with AgNps administration

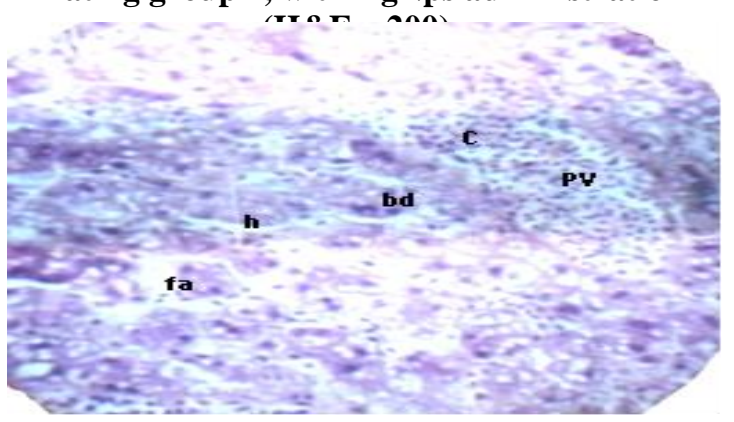

Fig. (1-f) T.S. in the liver of hens from the mating group 3, without AgNps administration (H\&E x

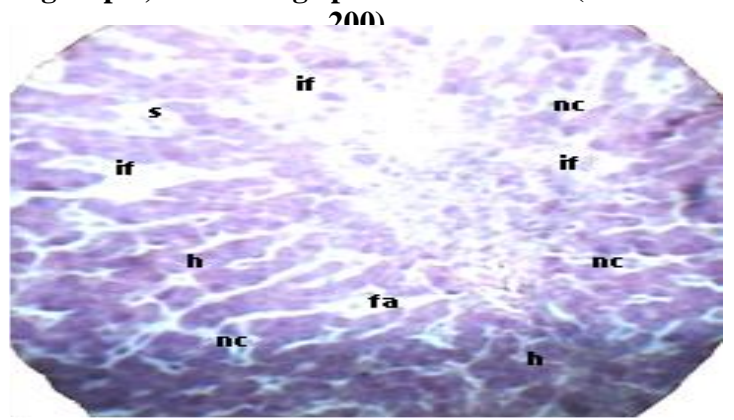

Fig. (1-h) T.S. in the liver of hens from the mating group 3, with AgNps administration

$P V$ : portal vein, $h$ : hepatocytes, $s$ : blood sinusoids, fa: fatty cirrhosis area, $c$ : congested area, If: infiltrable fluids, nc: necrotic area and bd: bile duct 


\section{Abd El-Azeem et al.}

\section{Ileum histology:}

The microscopical examination of the small intestine sections (ileum) as influenced by AgNps administration and age at mating are illustrated in Figures 2-a to 2-h. It is clear from sections in Fig. 2-a and 2-b that the villi height was greatly increased in old laying quails, regardless male's age. This increase was more obvious in Fig. 2-b which may reflect the productive status hens from of this group. Many goblet cells are present in the epithelial lining of the villi. Also, the muscular mucosa layer was well arranged, but its diameter is greater in Fig. 2-b than in Fig. 2-a. It is clear also that the size and number of the crypts of Lieberkühn were greater in the ileum section of hens in the mating group of young males with old females (Fig. 2-b) compared with the old $x$ old group (Fig. 2-a). It is difficult to attribute these histological changes to male's age, rather than the productive performance of females.

In young females (Fig. 2-c and 2-d), the number and size of the crypts were increased along with a hypertrophy of the epithelial lining of the villi. The height and diameter of the villi were detected with an obvious high columnar epithelial cells indicative of hyperactivity. This may responsible for an improvement in nutrients absorption and utilization in these young female groups, regardless male age.

Concerning the effect of AgNps administration on ileum histology, the present sections showed different magnitude depending on hens age. In old females (Fig. 2-e and 2-f) the histological examination showed considerable changes in the size of the muscular layer, number and size of the crypts, the presence of more or less lymphocytes along with same degenerative areas in the brush border of the epithelial surface. This effect was also observed, but with mild or little changes in young females' sections (Fig. 2-g and 2-h) which may reflect age-related response to AgNps administration. It appears from these observations that the combined effect of age and AgNps administration, showed a significant change in the ileum histology of laying quails. These changes include the number and size of the crypts of Lieberkühn accompanied by increased height of villi and their epithelial lining.

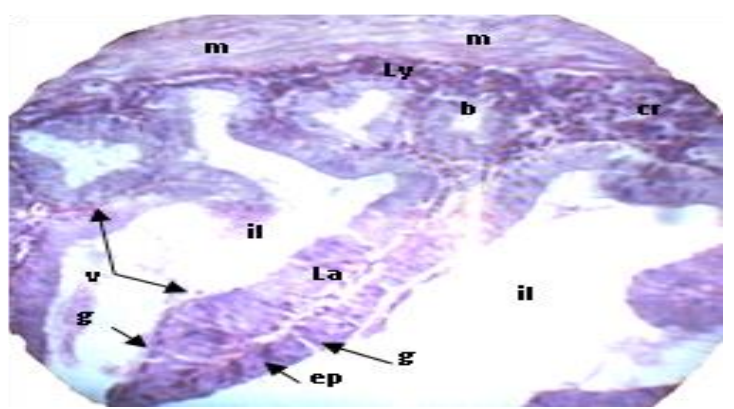

Fig. (2-a) T. S. in the ileum of hens from the mating group 2, without AgNps administration (H\&E x 200).

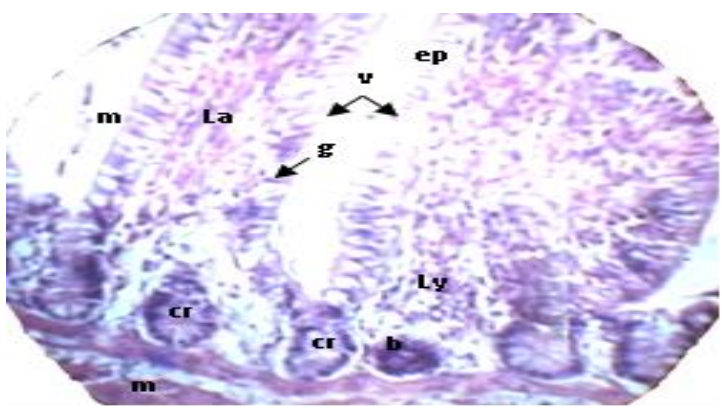

Fig. (2-c) T. S. in the ileum of hens from the mating group 1, without AgNps administration (H\&E x 200).

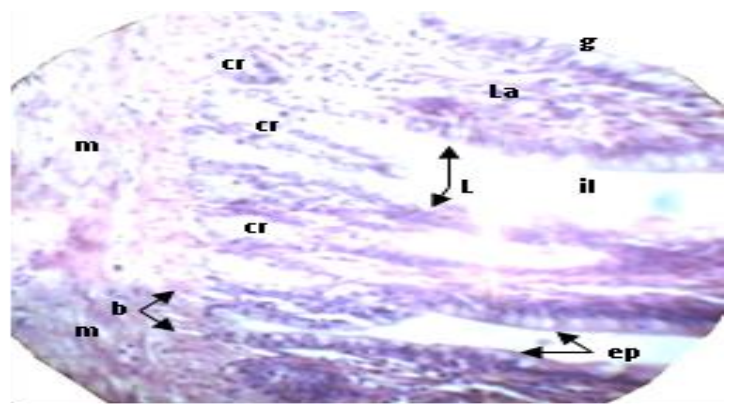

Fig. (2-b) T. S. in the ileum of hens from the mating group 4, without AgNps administration (H\&E x 200).

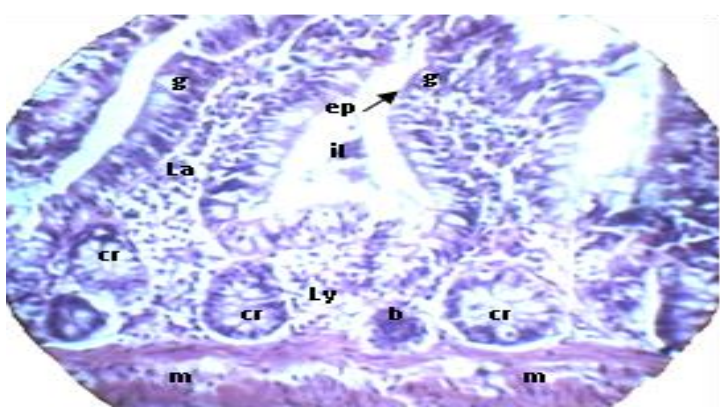

Fig. (2-d) T. S. in the ileum of hens from the mating group 3, without AgNps administration (H\&E x 200). 


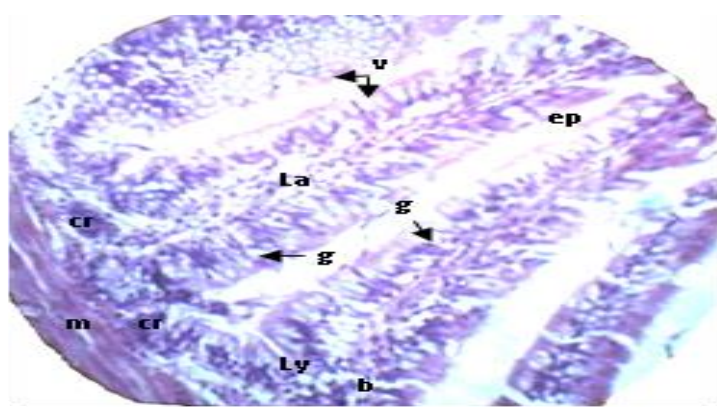

Fig. (2-e) T.S. in the ileum of hens from the mating group 2, with AgNps administration (H\&E x 200).

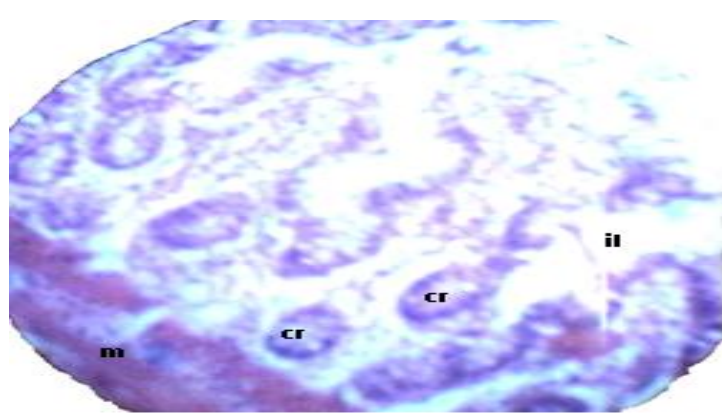

Fig. (2-g) T.S. in the ileum of hens from the mating group 1, with AgNps administration

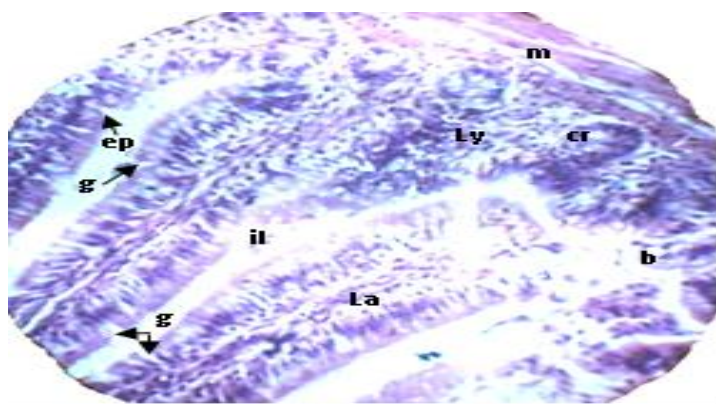

Fig. (2-f) T.S. in the ileum of hens from the mating group 4, with AgNps administration (H\&E x 200).

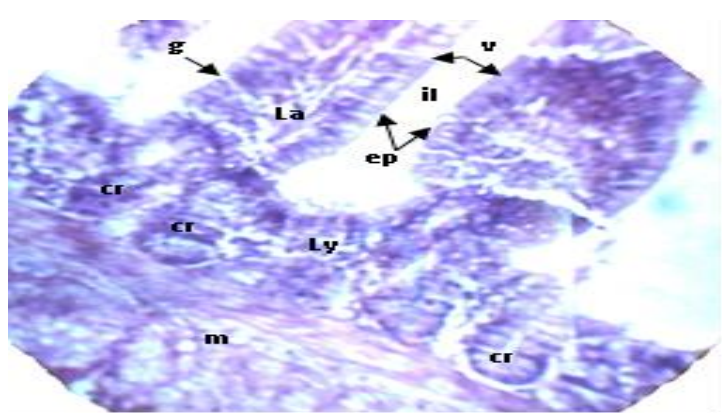

Fig. (2-h) T.S. in the ileum of hens from the mating group 3, with AgNps administration

B: blood vessels, cr: crypts of Lieberkühn, g: goblet cells, ep: epithelial cells, il: intestinal lumen, La: Lamina propria, Ly=Lymphocytes, m: muscularis layer and v: villi.

It is well known that the crypts of Lieberkühn had the ability to secrete fluids containing different vital substances essential for the internal micro-environment of the small intestine segments (Hodges, 1974). These fluids are rapidly absorbed from the villi lumena, making a circulation from crypts to villi which results in a watery vehicle supply for improving nutrients absorption, elaboration and production of antibodies and lymphocytes along with an increase in the number and size of goblet cells which secrete substances responsible for reducing the $\mathrm{pH}$ of the intestinal lumen, allowing for better environment to lactic acid bacteria. This may explain the changes in the productive performance of different groups. The negative effect of AgNps on ileum histology was also reported by Grodzik and Sawoza (2006), Sawosz et al. (2007) and Ahmadi et al. (2009).

\section{Testis histology:}

Histological examination of the testis sections as influenced by male age and AgNps administration are illustrated in Figures 3-a to 3-h. It is clear from Fig. 3-a and 3-b that the seminiferous tubules of old males were large with the lumen became wider and filled with numerous spermatozoa (Fig. 3-a). On the other hand, when old males were mated to young females, the seminiferous tubules (Fig. 3-b) appears to contains few spermatozoa in the lumen, however, the number of round or elongated spermatids was greatly increased. Microscopic sections showed also that the seminiferous epithelium lies on a connective tissue membrane, within the basement membrane is multilayered epithelial cells representing the successive stages of spermatogenesis. Sertoli cells are also presented in all sections with their pale-staining nuclei.

In young males, histological sections Fig. 3-c and 3-d showed a progressive proliferation of germ cells as indicated by many spermatocytes, spermatids and spermatozoa of different developmental stages. The darkstained matured germ cells may reflect hyperactivity and progressive spermatocytogenesis, especially in young males that mated with old females (Fig- 3-d). It appears that these histological observations are related to age change, and may be regulated by the level of plasma testosterone. It may be also that mating frequency and behaviors is different between old and young males. 


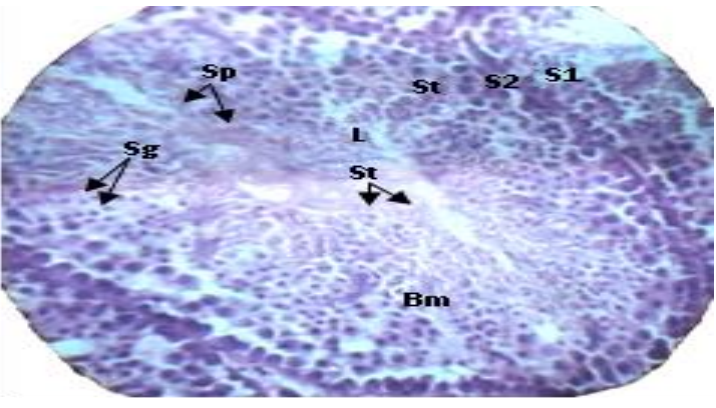

Fig. (3-a) T.S. in the testis from the mating group 2, without AgNps administration (H\&E x

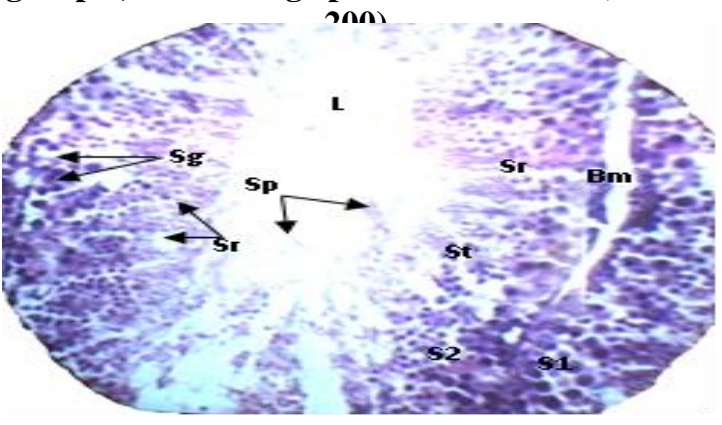

Fig. (3-c) T.S. in the testis from the mating group 3, without AgNps administration (H\&E x 200).

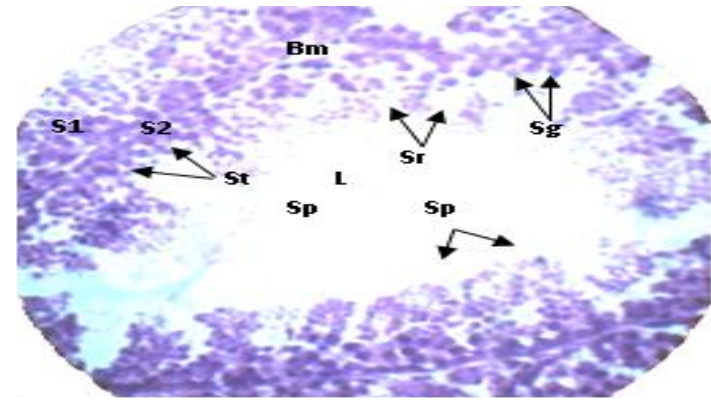

Fig. (3-e) T.S. in the testis from the mating group 2, with AgNps administration (H\&E x 200).

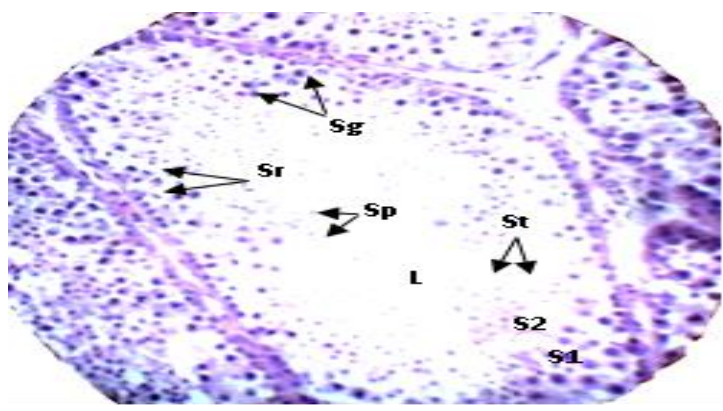

Fig. (3-g) T.S. in the testis from the mating group 3, with AgNps administration (H\&E x

Bm: Basement membrane, L: Lumen, S1: primary spermatocytes, S2: Secondary spermatocytes St: Spermatids, Sp:

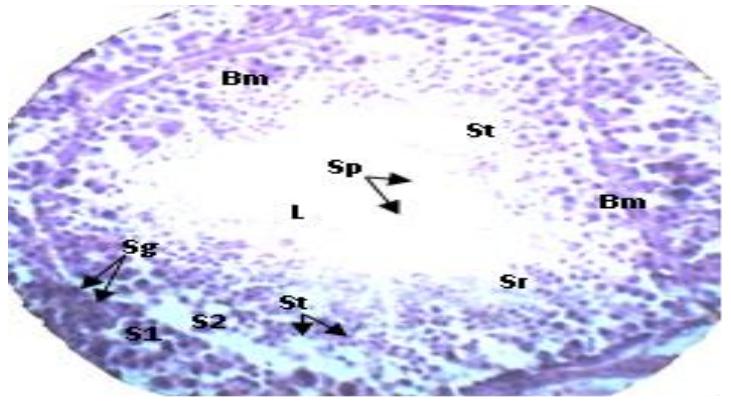

Fig. (3-b) T.S. in the testis from the mating group 1, without AgNps administration (H\&E x

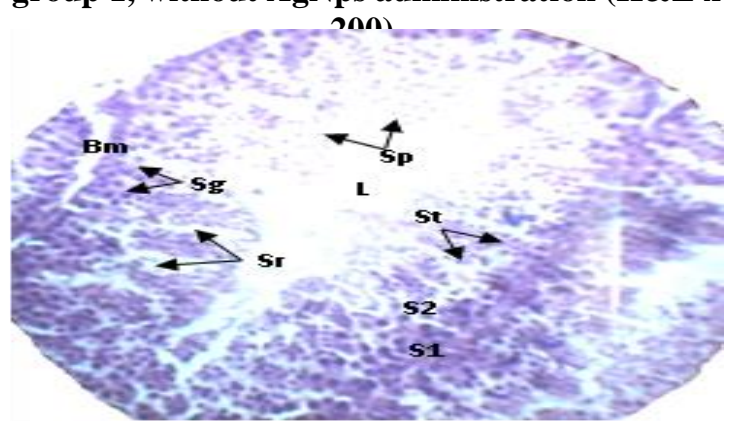

Fig. (3-d) T.S. in the testis from the mating group 4, without AgNps administration (H\&E x 200).

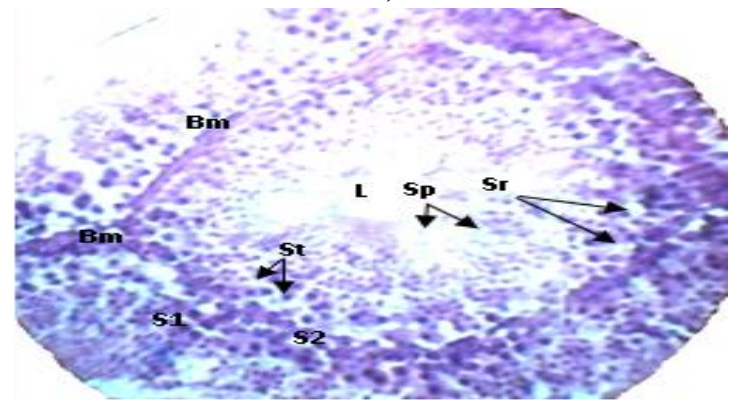

Fig. (3-f) T.S. in the testis from the mating group 1, with AgNps administration (H\&E x 200).

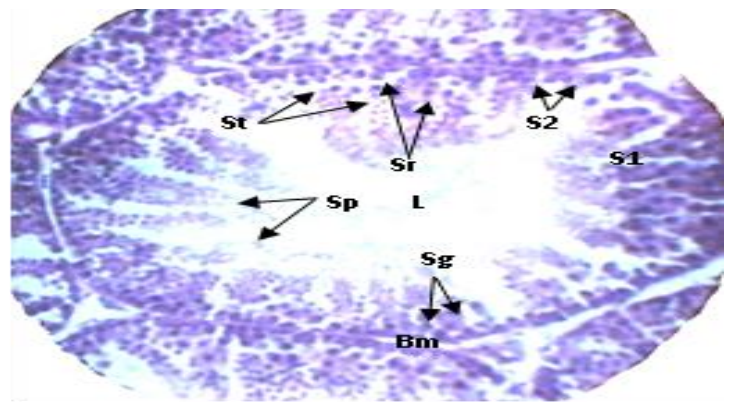

Fig. (3-h) T.S. in the testis from the mating group 4, with AgNps administration (H\&E x

Bm: Basement membrane, L: Lumen, S1: primary spermatocytes, S2: Secondary spermatocytes St: Spermatids, Sp: Spermatozoa, Sg: Spermatogonia and Sr: Sertoli cells.

The role of females age was not consistent in the present study, and needs further research. However, some earlier investigations demonstrate that sexual receptivity of females varies and plays a part in inducing successful mating and then stimulating some endocrine and behavioral responses in male chickens and 
quails (Wood-Gush, 1955; Sharp et al., 1964; Lake, 1984; Ottinger and Balthazart, 1986). Furthermore, the age-related changes in the histological structure of testis may be due to loss of gonadal steroids as there was a significant decrease in sexual behavior of males with age. This confirms the recent findings by Chen et al., (2004); Ottinger et al. (2002 a,b) and Ottinger et al. (2004).

Concerning the effect of AgNps administration combined with age at mating on the histological feature of testes, the present sections showed variable changes as illustrated in Figures, 3-e to 3-h. The seminiferous tubules of old males showed irregular distribution of the spermatogenic cells (Fig. 3-e) which may be due the combined effects of age and AgNps administration. The lumen of the tubules was larger with some morphologic and apoptotic aspects of testis (Fig. 3-f). This structure was more obvious in the testis section of old males that mated with old females, (Fig. 3-e), but it is mild in old males mated with young females (Fig. 3-f). Similar observations were detected, but with little detrimental effects on the spermatogenesis process. The germinal epithelium undergoes several proliferation and maturation processes, regardless AgNps administration (Fig. 3-g and 3-h). Since, there are numerous sperms, spermatids of different maturation stages, and Sertoli cells in the gross sections of young males, regardless of females age.

In the present study, there were no clear effect of AgNps on the histology of testis in quail males. It is probable that AgNps can induce some histological changes in tests histology, and this was more relevant in old males. These observations are consistent with the findings of Braydich-Stolle et al. (2005) and Sawosz et al. (2007) who found dramatic changes in spermatogonial cells induced by AgNps administration. In addition to necrotic areas, indicating that apoptosis had occurred.

\section{Sperm storage tubules (SST):}

Storage of sperms occurs in the so-called sperm-host glands or sperm storage glands, which are tubular glands lying within the corium of the mucosal folds of the utero-vaginal junction (Fig. 4-a1). There are about 25000 SST in the hen oviduct especially in the utero-vaginal junction (UVJ) each which may contain between a few or several hundred spermatozoa (Tingari and Lake, 1973; Etches, 1996).

Histological examination of SST from the UVJ of quail breeder hens as influenced by age at mating and AgNps administration are shown in Figures 4-a to 4-h. Fig. 4-a1 and 4-a2 showed that the UVJ folds in old females containing varying numbers of SST with some spermatozoa in the tubular lumen. The epithelial lining of the SST is columnar epithelium being non-ciliated in appearance. A similar observation was detected for old female in Fig. 4-b but with numerous spermatozoa being filled the SST lumen. These hens were mated with young males, which may explain the higher number of spermatozoa. There are also many lymphocytes in the lamina propria of the UVJ folds. In young females, the results show that the epithelial cells of the vaginal fold are very active, being highly columnar with a dark-stained nuclei (Fig. 4-c), however, the number of SST in Fig. 4-d (young $\hat{\partial} \mathrm{x}$ young + ) was abundant and contained large number of spermatozoa either in groups or mass.

They may be due to the effect of male age on the number of spermatozoa per ejaculate, which undoubtedly increased in young males. Also, histological sections revealed that AgNps administration had no effect on the SST structure along with the UVJ folds, however, many pale straining areas could be seen in

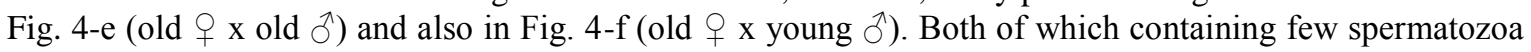
and more lymphocytes. This effect may be related to hens age and AgNps treatment.

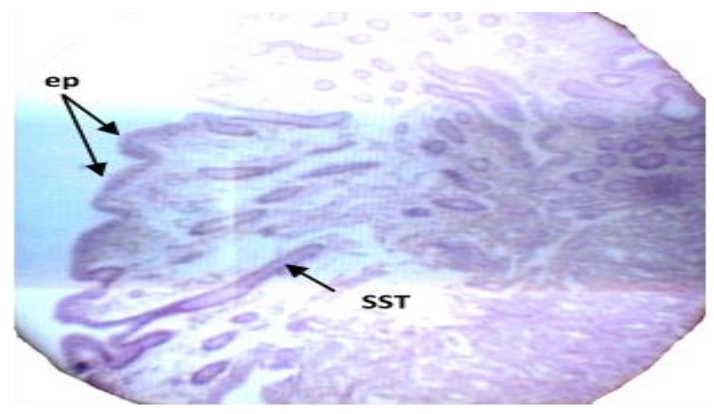

Fig. (4-a1) T.S. showing the SST in the oviduct from mating group 2, without AgNps administration (H\&E x 200).

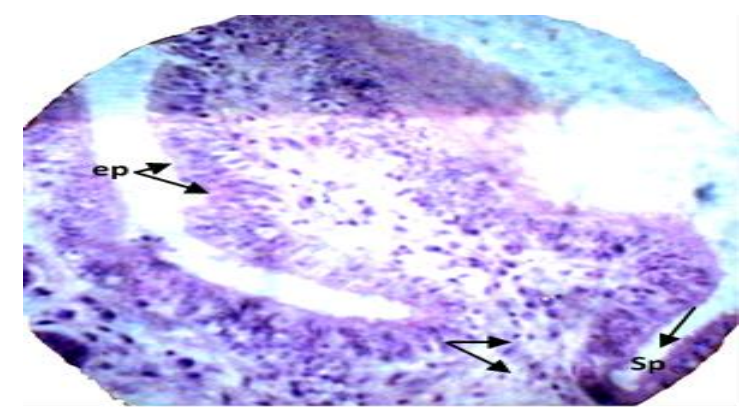

Fig. (4-a2) T.S. showing the SST in the oviduct from mating group 2, without AgNps administration (H\&E x 200). 


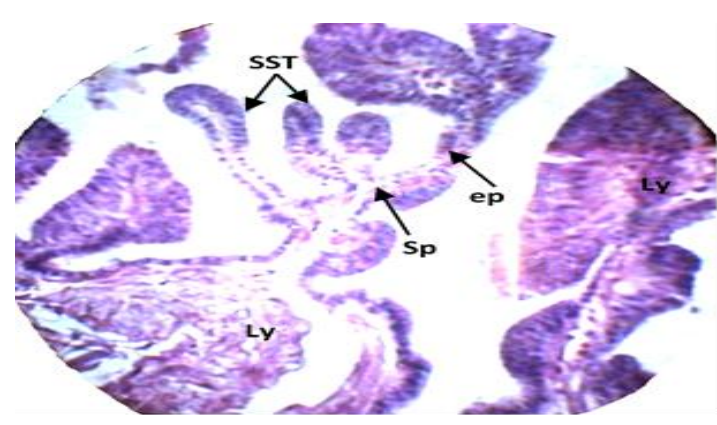

Fig. (4-b) T.S. showing the SST in the oviduct from mating group 4, without AgNps administration (H\&E x 200).

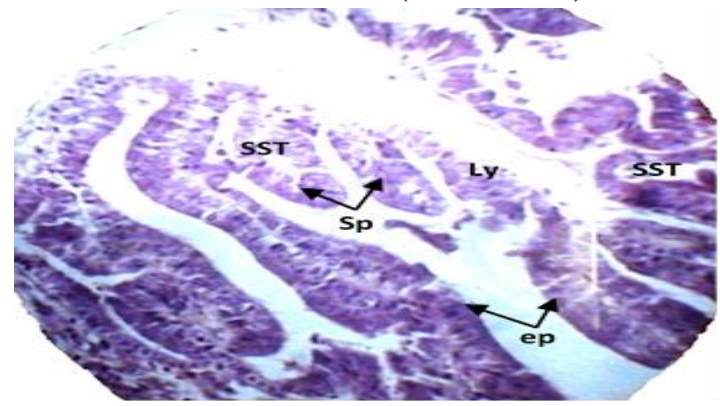

Fig. (4-d) T.S. showing the SST in the oviduct from mating group 3, without AgNps administration (H\&E x 200).

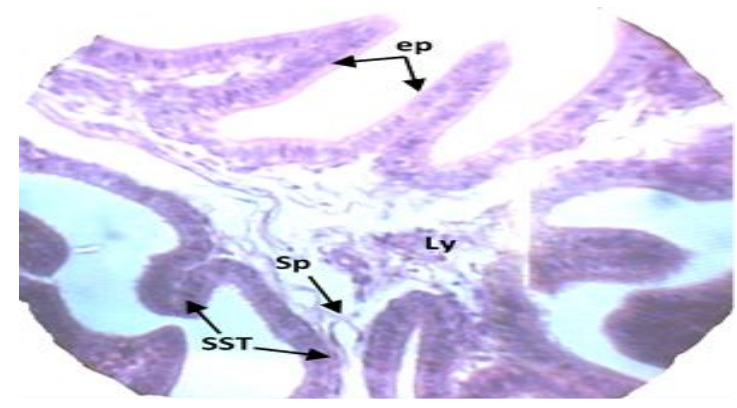

Fig. (4-f) T.S. showing the SST in the oviduct from mating group 4, with AgNps administration (H\&E x 200).

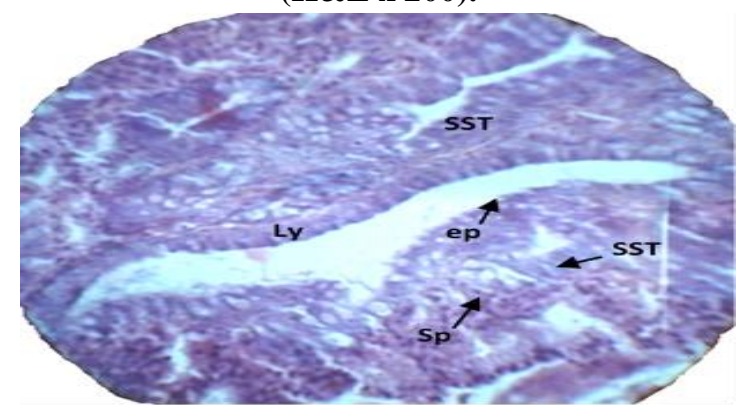

Fig. (4-h) T.S. showing the SST in the oviduct from mating group 3, with AgNps administration (H\&E x 200).

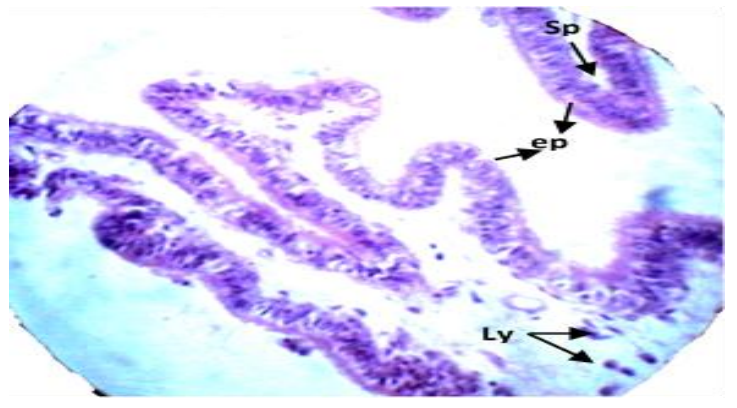

Fig. (4-c) T.S. showing the SST in the oviduct from mating group 1, without AgNps administration (H\&E x 200).

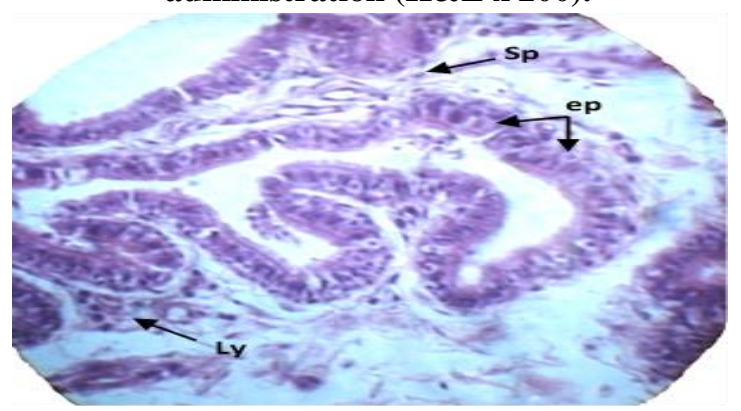

Fig. (4-e) T.S. showing the SST in the oviduct from mating group 2, with AgNps administration (H\&E x 200).

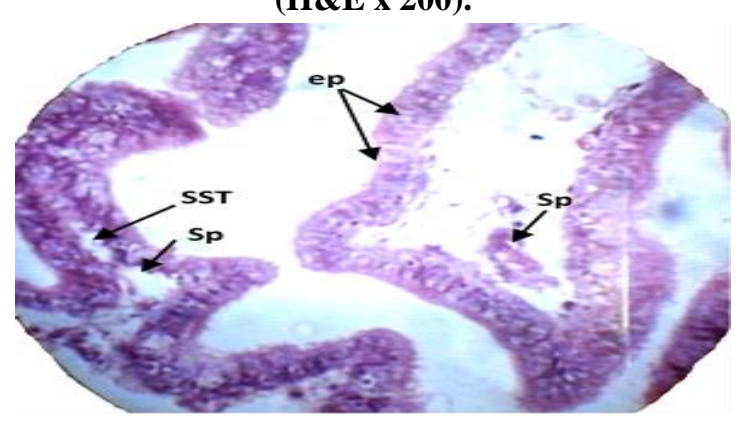

Fig. (4-g) T.S. showing the SST in the oviduct from mating group 1, with AgNps administration (H\&E x 200).

ep: Epithelial surface, Sp: Spermatozoa and Ly: Lymphocytes. 
In young females, either mated with old males (Fig. 4-g) or with young male (Fig. 4-h), the epithelial surface area is very active, being high columnar in the sections with numerous well-developed SST lying within the base of the vaginal folds. Many sperm masses could be seen, especially in Fig. 4-h which reflect the effect of male age in this respect.

From the previous results it appears that quail SST are well developed, functional and contains numerous spermatozoa in their lumen. These results confirm the recent findings by Holm and Ridderstrale (2002); Bakst (1992, 1998, and 2011) and Bakst et al. (2010). They studied the role of SST in fertility, their ultrastructure development and function in different avian species including Japanese quail. Furthermore, AgNps did not show any damaging properties on SST especially in young females, however, when hens age was considered, some histological changes could be seen.

\section{CONCLUSION}

From the results of the present study, it could be concluded that it is possible to improve the productive performance and healthy status of aged Japanese quail breeder stocks if the old age breeder is mated with younger ones. The magnitude of this effect could be achieved through the administration of AgNps in their drinking water.

\section{FUNDING}

This research was supported by National Research Centre, Egypt (\#11030114).

\section{REFERENCES}

Abd El-Hamid, Z. (1981). Histology: Part I Dar El Shaab for Press, Cairo, Egypt, pp: 113-118.

Abdel-Fattah, S. A. (1999). Physiological studies of gonadal hormones on the reproductive tract of female Japanese quail. M.Sc. Thesis, Fac. Agric. Ain-Shams University, Cairo, Egypt.

Ahmadi, F. (2012). Impact of different levels of silver nanoparticles (Ag-NPs) on performance, oxidative enzymes, and blood parameters in broiler chicks. Pak. Vet. J., 32(3): 325-328.

Ahmadi, J.; M. Irani and M. Choobchian (2009). Pathological study of intestine and liver in broiler chicks after treatment with different levels of silver nanoparticles. World App. Sci. J., 7: 28-32.

Agaviezor, B. O.; F. O. Ajnyi and O. A. Abedambo (2008). Genetic interrelationship existing between body weight, egg weight and egg internal quality traits. Proceedings of the $3^{\text {rd }}$ Annual Conference of the Animal Science Association of Nigeria. 56-57.

Ayorinde, K. L. and U. K. Oke (1995). The influence of juvenile body weight and two feeding regimes during the growing phase on growth performance and early lay characteristics of pullets. Nigeria J. Ani. Prod., 22(2): 101-107.

Bahie El-Deen, M.; W. S. El Tahawy; Y. A. Attia and M. A. Meky (2008). Inheritance of age at sexual maturity and its relationships with some production traits of Japanese quails. Egyptian. Poult. Sci., 28: 1217-1232.

Bahie El-Deen, M.; M. A. Kosba and A. S. A. Soliman (2009). Studies of some performance and blood constituents traits in Japanese quail. Egyptian. Poult. Sci., 29: 1187-1208.

Bakst, M. R. (1992). Observations on the turkey oviductal sperm-stor- age tubule using differential interference contrast microscopy. J. Reprod. Fertil., 95: 877-883.

Bakst, M. R. (1998). Structure of the avian oviduct with emphasis on sperm storage in poultry. J. Exp. Zool., 282: 618-626. 


\section{Abd El-Azeem et al.}

Bakst, M. R. (2011). Physiology and Endocrinology Symposium: Role of the oviduct in maintaining sustained fertility in hens. J. Ani. Sci., 89: 1323-1329.

Bakst, M. R.; A. M. Donoghue; D. E. Yoho; J. R. Moyle; S. M. Whipple; M. J. Camp; G. Q. Lin and R. K. Bramwell (2010). Comparisons of sperm storage tubule distribution and number in 4 strains of mature broiler breeders and in turkey hens before and after the onset of photostimulation. Poult. Sci., 89: 986992.

Braydich-Stolle, L.; S. Hussain; J. J. Schlager and M. C. Hofmann (2005). In vitro cytotoxicity of nanoparticles in mammalian germ line stem cells. Toxico. Sci., 88: 412-419.

Chen, H.; R. A. Irizarry; L. Luo and B. R. Zirkin (2004). Leydig cell gene expression: effects of age and calorie restriction. Exp. Gerontol., 39: 31-43.

Christians, J. and T. Williams (1999). Effects of exogenous 17 estradiol on the reproductive physiology and reproductive performance of European starlings (Sturnus vulgaris) J. Exp. Biol., 202: 2679-2685.

Duncan, D. B. (1955). Multiple range and multiple "F" test. Biometrics, 11: 1-42.

El-Afifi, Sh. F. and A. M. Abo-Taleb (2002). Calcium absorption and deposition in old egg-laying Japanese quail as affected by dietary supplementation with estradiol and cholicaciferol. Egypt. Poult. Sci., 22 (II): 855-868.

El-Wardany, I.; M. I. Shourrap; M. Madkour and Nafisa A. Abd El-Azeem (2016). Effect of Age at mating and silver nanoparticles administration on progeny productive performance and some blood constituents in Japanese quail. Inter. J. ChemTech Research, 9(8): 21-34.

Erensayin, C.; E. Baser; S. Aktan and K. K. Ucukyilmaz (2002). Influence of male to female ratios on reproductive performance of Japanese quail. J. Central Ani; Res. Institute, 12: 51-54.

Etches, R. J. (1996). Reproduction in poultry. CAB International, Oxford.

Farzinpour, A. and N. Karashi (2013). The effects of nanosilver on egg quality traits in laying Japanese quail. Appl. Nanosci., 3(2): 95-99.

Fondevila, M.; R. Herrer; M. C. Casallas; L. Abecia and J. J. Ducha (2009). Silver nanoparticlesas a potential antimicrobial additive for weaned pigs. Ani. Feed Sci. Tech., 150: 259-269.

Gilbert, A. B.; M. M. Perry; D. Waddington and M. A. Hardie (1983). Role of atresia in establishing the follicular hierarchy in the ovary of the domestic hen (Gallus domesticus) J Reprod Fertil., 69: 221-227.

Gopi, M.; B. Pearlin; R. D. Kumar; M. Shanmathy and G. Prabakar (2017). Role of nanoparticles in animal and poultry nutrition: modes of action and applications in formulating feed additives and food processing. Int. J. Pharmaco., 13: 724-731.

Grodzik, M. and E. Sawosz (2006). The influence of silver nano particles on chicken embryo development and bursa of Fabricius morphology. J. Ani. Feed Sci., 15 (Suppl. 1): 111-114.

Hansen, K. K.; R. J. Kittok; G. Sarath; C. F. Toombs; N. Caceres and M. M. M. Beck (2003). Estrogen receptor- $\alpha$ populations change with age in commercial laying hens. Poult. Sci., 82: 1624-1629.

Hodges, R. D. (1974). The Histology of the Fowl. R.D. Hodges. Academic Press, London, New York.

Holm, L. and Y. Ridderstråle (2002). Development of sperm storage tubules in the quail during sexual maturation. J. Exp. Zool., 292: 200-205.

Holmes, D. J.; S. L. Thomsm; J. Wu and M. A. Ottinger (2003). Reproduction aging in female birds. Exp. Gerontol., 38 (7):751-756.

Ipek, A.; U. Sahan and B. Yilmaz (2004). The effect of live weight, male to female ratio and breeder age on reproduction performance in Japanese quails (Coturnix coturnix japonica). South African J. Ani. Sci. 34 (2):130-134.

Johnson, A. L. (2000). Reproduction in the Female. In: Sturkie's Avian Physiology, 5 edn, pp 569-596. Ed GC Whittow. New York: Academic Press.

Khalifa, M. A.; M. K. Shebaita; G. A. R. Kamar and M. A. Abdou (1983). Effect of thyroxine, estradiol and ACTH on egg characters and some reproductive organs in Fayoumi. Egypt. J. Ani. Prod., 23: 119-126. 
Lake, P. E. (1984). The male in reproduction. In: Physiology and Biochemistry of the domestic fowl. Vol. 5., B.M. Freeman, ed. Academic Press, London, PP. 381-405.

Lien, R. J.; J. R. Cain and D. W. Forrest (1985). The influence of exogenous estradiol on bobwhite quail (Colinus virginianus) reproductive systems. Comparative Biochemistry and Physiology Part A: Physiology, 80(3): 433-436.

Loghman, A.; S. H. Iraj; D. A. Naghi and M. Pejman (2012). Histopathologic and apoptotic effect of nanosilver in liver of broiler chickens. African J. Biotec., 11(22): 6207-6211.

Marambio-Jones, C. and E. M. V. Hoek (2010). "A review of the antibacterial effects of silver nanomaterials and potential implications for human health and the environment." J Nanopart Res 12: 1531-1551.

Meky, M. A. M. (2007). Effect of age at sexual maturity on some production traits of Japanese quails. M.Sc. thesis, Fac. of Agric., Alex. Univ., Egypt.

Nazlıgül, A.; K. Türkyılmaz and H. E. Bardakçığlu (2001). Japon bıldırcınlarında (Coturnix coturnix japonica) bazı verim ve yumurta kalite özellikleri üzerinde bir araştırma (Turkish of: A study on some production traits and egg quality characteristics of Japanese quail (Coturnix coturnix japonica)). Tr. J. Vet. Ani. Sci., 25: 1007-1013.

NRC, (1994). Nutrient Requirements of Poultry. $9^{\text {th }}$ ed. National Academy Press, Washington, D.C. USA.

Ottinger, M. A. and J. Balthazart (1986). Altered endocrine and behavioral responses with reproductive aging in the male Japanese quail. Horm. Behav., 20: 83-94.

Ottinger, M. A.; M. Abdelnabi; Q. Li; K. Chen; N. Thompson; N. Harada; C. Viglietti-Panzica and G. C. Panzica (2004). The Japanese quail: a model for studying reproductive aging of hypothalamic systems. Exp. Gerontol., 39: 1679-1693.

Ottinger, M. A.; K. Kubakawa; M. Kikuchi; N. Thompson and S. Ishii (2002a). Effects of exogenous testosterone on testicular LH and FSH receptors during aging. Exp. Biol. Med., 227 (9), 830-836.

Ottinger, M. A.; N. Thompson and P. Micevych (2002b). Delta opioid receptors colocalize on a subset of tyrosine hydroxylase containing neurons in the hypothalamus, The $32^{\text {nd }}$ Soc. Neurosci. Annu. Meet. Nov. 3-7, Orlando, USA.

Pageaux, J. F.; C. Laugier; D. Pal and H. Pacheco (1984). Development of the oviduct in quail during sexual maturation in relation to plasma concentrations of oestradiol and progesterone. J. Endo. 100: 167-173.

Rezaei, A.; A. Farzinpour; A. Vaziry and A. Jalili (2018). Effects of silver nanoparticles on hematological parameters and hepatorenal functions in laying Japanese quails. Biologi. Trace Element Res., 185: 475485.

SAS (1998). SAS/STAT®User's Guide: Statistics Ver. 6.04, $4^{\text {th }}$ ed. SAS Institute Inc., Cary, NC., U.S.A.

Sawosz, E.; M. Bineka; M. Grodzika; M. Zieliñskaa; P. Sysaa; M. Szmidt; T. Niemiec and A. Chwalibog (2007). Influence of hydrocolloidal silver nanoparticles on gastrointestinal microflora and morphology of enterocytes of quails. Archives Ani. Nut., 61(6): 444-451.

Sawosz, E.; M. Grodzik; M. Zielinska; T. Niemiec; B. Olszanska and A. Chwalibog (2009). Nanoparticles of silver do not affect growth, development and DNA oxidative damage in chicken embryos. Europ. Poult. Sci., 73(3): 208-213.

Sawosz, F.; L. Pineda; A. Hotowy; P. Hyttel; E. Sawosz; M. Szmidt; T. Niemiec and A. Chwalibog (2012). Nano-nutrition of chicken embryos. The effect of silver nanoparticles and glutamine on molecular responses, and the morphology of pectoral muscle. Baltic J. Comp. Clin. Sys. Biolog., 2: 29-45.

Sharp, P. J.; R. T. Talbot; G. M. Main; I. C. Dunn; H. M. Fraser; P. B. Siegel and H. S. Siegel (1964). Rearing methods and subsequent sexual behaviour of male chickens. Ani. Behav., 12:270-272.

Silversides, F. G. and T. A. Scott (2001). Effect of storage and layer age on quality of eggs from two lines of hens. Poult. Sci., 80: 1240-1245.

Sondi, I. and B. Salopek-Sondi (2004). Silver nanoparticles as antimicrobial agent: a case study on E. coli as a model for gram-negative bacteria. J. Colloid Interface Sci., 275(1): 177-182. 


\section{Abd El-Azeem et al.}

Tingari, M. D. and P. E. Lake (1973). Ultrastructural studies on the uterovaginal sperm-host glands of the domestic hen (Gallus domesticus). J. Reprod. Fert., 43: 423-431.

Wood-Gush, D. G. M. (1955). The behaviour of the domestic chicken: a review of literature. Ani. Behav., 3:81-110

Xia, Y.; X. Jiang; J. Zhang; M. Lin; X. Tang; J. Zhang and H. Liu (2017). Synthesis and characterization of antimicrobial nanosilver/diatomite nanocomposites and its water treatment application. Appl. Surf. Sci., 396: $1760-1764$.

Yoshimura, Y.; S. A. Tischkau and J. M. Bahr (1994). Destruction of the germinal disc region of an immature preovulatory follicle suppress follicular maturation and ovulation. Biol. Reprod., 51: 229-233.

\section{الأداء الإتتاجي والاستجابات الهيستولوجية للعمر عند التزاوج واضافة جزيئات النانو فضة للسمان الياباني}

$$
\begin{aligned}
& \text { نفيسة أحمد عبد العظيم1، محمود مدكور 1، أسامة محم أبو العزب1 و إبراهيم الوردانى² } \\
& 1 \text { قسم الإنتاج الحيواني- المركز القومي للبحوثـ الدقيـ الجيزةــ مصر. }
\end{aligned}
$$

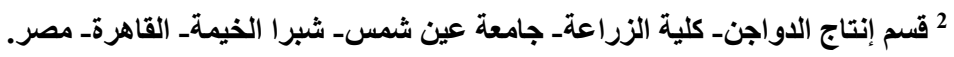

تم استخدام عدد 64 من ذكور و 192 من إناث السمان الياباني البالغ وتم تقسيمهم إلى مجمو عتين من أعمار مختلفة (الطيور الكبيرة

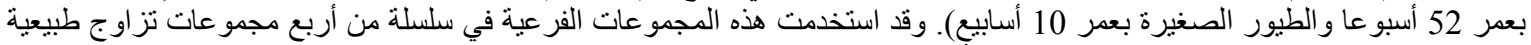

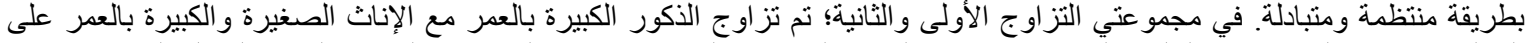

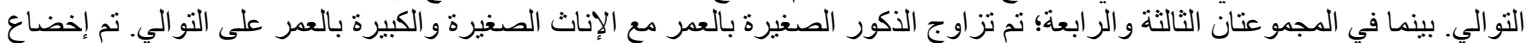

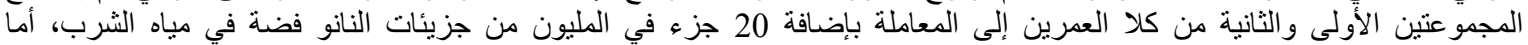

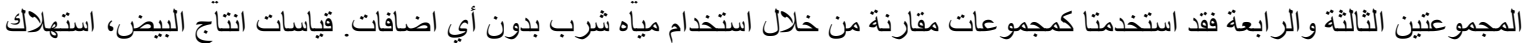

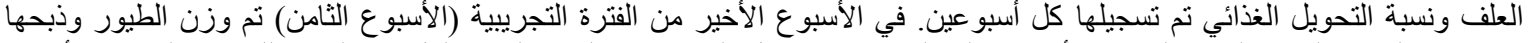

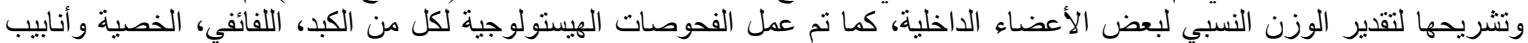
تخزين الحيو انات المنوية.

أوضحت النتائج أن أوزان البيض تأثرت معنويا بزيادة العمر في قطعان السمان الياباني بالمقارنة بالقطعان الصغيرة في العمر . كما

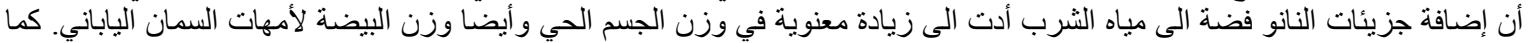

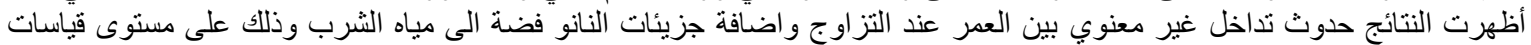

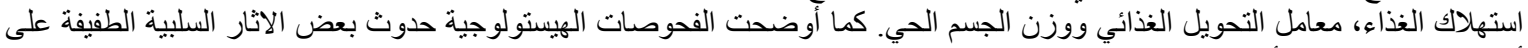
أنسجة الكبد و اللفائفي لأمهات السمان النهان الياباني.

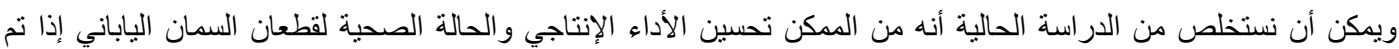

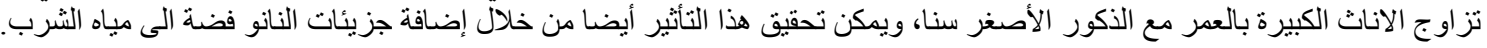

